\title{
Seminario Internacional Definiciones étnicas, organización social y estrategias políticas en la Chiquitania y el Chaco
}

Isabelle Combès

\section{(2) OpenEdition Journals}

Edición electrónica

URL: http://journals.openedition.org/bifea/5040

DOI: $10.4000 /$ bifea. 5040

ISSN: 2076-5827

Editor

Institut Français d'Études Andines

Edición impresa

Fecha de publicación: 1 diciembre 2005

Paginación: 487-488

ISSN: 0303-7495

\section{Referencia electrónica}

Isabelle Combès, « Seminario Internacional Definiciones étnicas, organización social y estrategias políticas en la Chiquitania y el Chaco », Bulletin de l'Institut français d'études andines [En línea], 34 (3) 2005, Publicado el 08 diciembre 2005, consultado el 02 diciembre 2020. URL : http:// journals.openedition.org/bifea/5040; DOl : https://doi.org/10.4000/bifea.5040

\section{(c)}

Les contenus du Bulletin de l'Institut français d'études andines sont mis à disposition selon les termes de la licence Creative Commons Attribution - Pas d'Utilisation Commerciale - Pas de Modification 4.0 International. 


\section{Eventos}

\section{SEMINARIO INTERNACIONAL DEFINICIONES ÉTNICAS, ORGANIZACIÓN SOCIAL Y ESTRATEGIAS POLÍTICAS EN LA CHIQUITANIA Y EL CHACO}

Del 5 al 7 de octubre de 2005, ha tenido lugar en Santa Cruz de la Sierra (Bolivia) un seminario internacional organizado por el IFEA en colaboración con varios de sus socios locales como el PIEB (Programa de Investigación Estratégica en Bolivia) y el museo de historia de la universidad de Santa Cruz.

Este evento ha reunido a especialistas de diferentes disciplinas (antropología, historia, sociología, derecho y psicología) y de diferentes países (Bolivia, Francia, Alemania, Argentina, Estados Unidos, Canadá y Brasil) alrededor del tema Definiciones étnicas, organización social y estrategias políticas en la Chiquitania y el Chaco.

El Gran Chaco es una extensa región ecológica que se extiende sobre cuatro países: Paraguay, Argentina, Bolivia y Brasil. Fue y sigue siendo una zona de encuentros e intercambios entre Andes y Amazonía; zona árida y de difícil acceso, quedó en gran parte como una tierra incógnita durante la Colonia y sigue poco poblado en la actualidad por los blancos y mestizos, que se concentran en sus fronteras más fértiles. Varias son las etnias que vivieron y siguen viviendo en el Chaco boliviano. Identificarlas es tarea ardua. Los españoles coloniales recogieron una enorme profusión de nombres que no reflejan necesariamente una situación étnica objetiva. Los isoseños actuales, para dar un solo ejemplo, fueron igualmente conocidos en el transcurso de la historia como chané, tapuy, isoseños, chiriguanos y guaraní. El vals de las denominaciones y autodenominaciones étnicas continúa hoy, y está estrechamente ligado con las nuevas estrategias políticas indígenas que surgieron a partir de la década de 1980. ¿Por qué la Asamblea del Pueblo Guaraní no se llama más "chiriguano", por qué incluye entre sus miembros a etnias de origen arawak? ¿Por qué los tapieté de Bolivia se afiliaron tanto a la Asamblea Guaraní como a la organización weenhayek, para acabar abandonándolas a ambas? ¿Cómo se sustentan las organizaciones pan-indígenas que reúnen a etnias antaño enemigas?

Uno de los objetivos de este seminario fue intentar dar respuestas a esta clase de preguntas, cada día más apremiantes y más actuales dado el peso político alcanzado por las organizaciones 
indígenas. Otro objetivo fue realzar el aporte de los estudios chaqueños para la historia y antropología sudamericanas.

Además de la calidad de las diferentes exposiciones, lo que llamó la atención durante este encuentro es a la vez la diversidad del público -estudiantes, investigadores, organizaciones no gubernamentales, proyectos estatales y representantes indígenas- y su interés por estos temas y estas regiones. Santa Cruz es una ciudad algo postergada en los debates intelectuales, y donde no existe una tradición académica de investigación social. Existe, sin embargo, una muy sincera y apremiante sed de conocimientos en este medio, que este seminario ayudó de alguna manera a despertar. Las actas del mismo, que recogerán cada una de las ponencias de los especialistas invitados, serán publicadas en 2006 por el IFEA en colaboración con instituciones locales. 